\title{
COMMENTARIES: ABORIGINAL PEOPLES AND THE CONSTITUTION
}

The following papers are the texts of remarks made in response to Professor Sanders'discussion of aboriginal rights and the constitution. Wallace Many Fingers presents the Indian approach and reactions to governmental actions with regard to aboriginal rights. Professor Gurston Dacks considers the possible extent of those rights and the difficulty of establishing aboriginal title.

\section{WALLACE MANY FINGERS *}

I have been asked to comment on the presentation by Doug Sanders. He is a trusted advisor to many major Indian political figures and has been for a number of years. I also have some comments on the federal government's patriation package.

The first observation I would like to make is that there is a real temptation to view the constitutional position of the Indian purely in terms of the way in which Canadian or British courts have looked at the question. Mr. Sanders' review indicates that the treatment given to Indian rights by the courts has not been very favourable. These are, in our view, not legal matters but political matters which should be resolved in a political manner through negotiations.

I would like to give you the Indian view. What is the dominant political ideology among Indian peoples? How do they view what is going on? What we can piece together both from our own history and from the written history of the dominant culture is that the existing relationship is a lot different from what has been described. If I may attempt to describe this relationship, it is one in which Indian nations, the first nations of Canada, have treaties with the British Crown. There is a political association with the British Crown because of the treaties.

Conceivably then, the B.N.A. Act is a document of law drafted and made by the British Parliament which says that Canada shall have selfgovernment and which outlines the terms of the federal union. But Indians, having this treaty relationship, which gives them a horizontal relationship rather than a vertical one with the Crown, are clearly placed in a different position that what is currently being enunciated. Section 91(24) was a grant from Britain to Canada to administer responsibilities that Britain had assumed by its treaties. The treaty negotiations reveal that the commissioners made promises and perhaps acted a little pretentiously on behalf of the Queen. Nevertheless, that is what happened and that is the history. We do share a common bond, and that is the Crown; the roots of law in Canada are derived from the Crown. And we respect this because we have the treaties.

The matter of Indian consent has not been adequately addressed. Colonial law (that is the system we are trying to work with now whereby the mother country gives its dominions some self-government or finally decides to let

- Of the Blood Reserve; London Lobby Liaison Officer, and member of the Indian Association of Alberta. 
them go), lays the ground rules that Indians are associated with and take their protection from the Crown. But Canadian courts have diminished the status of our treaties by the very act of looking at them. In most cases in which treaties have been dealt with, we have not been direct parties. It was a federal crime to take Indian claims to court, to raise money to pursue Indian claims or in fact to organize to pursue Indian claims until the 1930's. So it has been a long and difficult road. Nevertheless our treaties are binding agreements with international implications and should not be set aside easily. By international law we retain what we call our internal sovereignty because this right was not surrendered when we signed the treaties with the Crown. Various American cases have considered international law and assimilated it into the treatment of Indians in the United States. I am referring to the Cherokee cases in Georgia, where the Supreme Court held that Indians, by taking their protection from treaties, do not lose the right to selfgovernment.

It has been said that Indian nations want to be part of a progressive and a dynamic country - one where there is liberty and equality. It has been further stated that Indians have the right to be free and equal, but our collective rights as aboriginal peoples have not been provided in Trudeau's Charter except in a negative manner. We assert that by the terms of the treaties an intergovernmental agreement was established which provided for some distance between our two communities and by which we retain the right to a certain separate existence. The conclusion here is that special status for Indians, aboriginal rights, is a constitutional fact. So the amendments do not achieve much where they recognize that the aboriginal and treaty rights exist, because we always believed that was the case. The negotiations that are now taking place in non-treaty areas for the extinguishment of aboriginal title are another indication that these Indian rights do exist.

Indians as a national community did not consciously decide to enter the country. As a national community, despite what the press has said, we have not supported the federal government in its move to patriate the constitution. But what do we want? What are we bargaining for? Our position has been consistent in the recent past: we want entrenchment. If we are to be a part of this country, we want our rights as original peoples, our collective and other rights, put in the constitution to protect our existence as a distinct political community. The federal government has denied us this by saying our Indian rights are not well defined. They propose that existing rights, the rights that the courts have defined (traditional usages, not ownership, and treaty rights as mercantile contracts) be entrenched. We want our rights protected so they cannot be removed without our consent and believe this a reasonable position to take.

We have attempted to participate in the Canadian political process. A consideration of that participation in the past shows that Indians were not even considered proper citizens until 1957. They were not given the vote until 1960. Under those terms and conditions participation was minimal. But we have attempted to participate in the process of formulating a new constitution. People in Canada think that the constituent authority rests in the people; if they decide to vote in a referendum, they are the constituent authority. However, the constituent authority involved in the current proposals, the body that will change the constitution, is the first ministers. We have attempted to participate there and have been turned away. We have persisted, and have made a number of points to the first ministers: first, that 
only Indians can speak for Indians, that only Indians can represent Indians in constitutional discussions; and second, that we would be prepared to take action to protect ourselves against proposed amendments adverse to our interests.

The major deficiency in the package is that it fails to secure for the Indian people a position within Canada, and does not provide for the protection of Indian rights and Indian lands from arbitrary seizure and confiscation. This has been the root of the problem. So, as far as we are concerned, the protection is not acceptable in the current form.

We have proposed a thirteenth province. If you add up all the Indian reserved lands, not including territories or other unorganized areas, the total Indian land base in Canada on reserves is equal to that of Nova Scotia. So we have a significant property interest which must be taken into account. We have argued that it is perhaps time that the existing constitution be used to provide for the entry of new provinces; to provide for a thirteenth province for Indians. If we were to get our status on par with the provinces, we would be willing to be a part of an amending formula which calls for unanimous consent from the different constituent agents. Another alternative is a veto or some involvement in areas that affect us directly. Of course, the veto is more acceptable to us, but I believe there are now some negotiations to achieve some involvement falling short of a veto. It is uncertain whether that will be acceptable.

The reality is that federal and provincial governments do not want to see the Indian land base and Indian jurisdiction enhanced. Provinces want to maintain their legal and political predominance over Indians. This is particularly so in areas where they have no business in the internal affairs of Indian governments, such as the areas of policing and child care.

There have been numerous trips made to England to remind the English of the responsibilities which they assumed as an imperial power. Indian lobbyists have been quite successful in England. If we are not successful in Canada, we will attempt to have the British install what we feel are reasonable provisions to protect our rights and interests. If negotiations break down we will go to the U.N..

Following our last first nations conference we met with the representative of the Secretary General of the United Nations and pointed out to him that Canada was not honouring responsibilities that it had inherited from Britain or honouring its treaties. We also attempted to obtain a sponsor to have this trusteeship responsibility removed from Canada and given to the United Nations in trilateral negotiations. Our options are by no means closed at this time.

There is one question which has not been addressed to date. That is the question of resources and the Indian role in this area. To do justice to this issue, we must look at the treaties. As Professor Sanders has stated, the question of the exact content of the treaties is still open and remains unresolved. Why is that? For fifty years we have been telling the government that they are unfair, and that we should take a second look at them, and they have consistently refused to open discussion on these treaties. Indians are not reclaiming the country because Canada has broken its treaty obligations. That is not our understanding. Our understanding is that we agreed to share the lands. The treaties are silent as to minerals, but our elders, as tenders of extensive historical documentation, have said that when we signed the treaties all that we gave up was the right to use the topsoil. 
We pointed out to the Province of Alberta several years ago that we have a right to resources off the reserves. We struck a bargain with the Province of Alberta to the effect that they would stay out of our internal affairs. I do not know if they have honoured that. They also agreed that they would assist us with development funds. It is certain that they have not done that. The provinces say that they do not want to encourage separateness. This puts them in a policy dilemma. A number of their prominent politicians have said we do not want to create a jurisdiction within a jurisdiction. Whatever that means.

So what are aboriginal rights? Aboriginal rights are in fact the national rights of Indian nations, which include claims to territory. The territorial claims of Indian nations pre-date those of the British, Canadian and local provincial governments. Indian territorial disputes are of an international character, not to be governed by private law contracts. Our view is that reserves are homelands where Indians can be Indians. They were promised as long as the sun shines, the river flows, and the grass grows. And we were told that we would have continued access to resources off the reserve, and that we would not be contained simply on a small plot of land. In most cases, the area was that of a postage stamp. However, gradually economic and other barriers have been enacted to prevent us from utilizing our rights to resources off the reserves. The original agreement was that we would have our reserves and that we would use these ourselves but that we would be sharing the lands off the reserves. In our Canadian legal system now, the majority of Indian claims are what we call treaty entitlement claims. These relate to lands which were promised to the Indians 100 years ago, when the treaties were signed. Of course, it takes the government a long time to respond and it has taken them over 100 years to carry out what they promised in the treaties. The trust that they assumed has not been honoured. These entitlement claims have not progressed because the present constitution, as established by the Natural Resource Transfer Agreements of 1930, gives the provinces a role in handing over the land. First the federal government has to say, "you have got a good claim"; then we have to talk to the Province and say, "give us our land, we are entitled to it". The answer will be "no", as was said to the Fort Chipewyan Cree Band of Northern Alberta. They will concede less than $5 \%$ of what our entitlement is and keep the mineral rights.

These disputes are boundary disputes. They are territorial disputes. In Alberta they are becoming a real problem. Witness the blockade on the Blood reserve this spring, when they became extremely frustrated with the procedures involved in taking their claims to court. The federal proposal strengthens the land rights of the provinces but not those of Indian government. Our land rights have been decided by the courts to mean traditional usage in recent cases, but we maintain that Indian claims exist as a matter of international law. The patriation package states that treaty rights will be recognized and confirmed. This contributes absolutely nothing to the peaceful negotiation of treaty disputes. In fact, it may limit the ability of Indian tribes to reopen the treaties if they choose to do so. The President of the Indian Association told Canadian parliamentarians in his brief that Alberta Indians intended to contest colonial or unequal treaties in law in the future. This issue is of real concern to us and is not addressed in the amendments made by the government.

Section 91(24) of the B.N.A. Act has been interpreted by the Canadian government to mean that it has total plenary authority over Indians. What does this mean? Our proposals, which we feel are eminently reasonable, aim at 
limiting the arbitrary power of the federal government. Some of us say that, in international law, huge portions of federal legislation are illegal, especially those which assume jurisdiction where there is no Indian consent. By international law, people may acquire jurisdiction over others' territory by discovering it (if it is vacant), or by conquering the people (if it is occupied), or by occupying it with their agreement. We were not conquered. Because we were here, the only major instrument by which we could agree to a system of shared jurisdiction was the treaties. Treaty jurisdiction has been downplayed in the proposals.

In our negotiations we have said that we want Indian governments recognized in the constitution. Indians should have available greater selfdetermination of the criteria affecting their social and economic structures. And, as responsible governments, they should have access to adequate physical resources from the national treasury. These demands have been ignored and the prospects for Indian government are not good now.

There is a grass roots process whereby the people retain sovereignty and pass it on to their elected officials. This may be the fundamental difference in our perceptions. It is said that the power comes from the people, and is delegated to their agents. But Canadians went to Britain to ask the Crown to enact the B.N.A. Act to give their own legislatures power. The process of making a real constitution should surely be one from the grass roots up, instead of from the top down.

This country was ours and surely we have a right to share in the benefits of our society and to maintain our collective rights. Bargaining and negotiation continue. It is difficult to assess the content of the proposals until they are a firm package. Before we can decide as a national community whether or not we want to support patriation (that option is still open to us), there has to be Indian consent to future changes, Indian participation in future changes, and recognition of the Indian right to self-determination. Whether or not these deficiencies can be corrected in time to prevent a collision between the Indian tribes and the provinces is questionable. I doubt it.

In 1980 the Department of Indian Affairs released a report entitled "Indian Conditions", citing statistical measures of human well-being for Indians. They reported that there was an increase in social problems among off-reserve Indians, including high rates of alcohol abuse and welfare dependency. Their life expectancy is still ten years beneath the national average. Indians are three times as prone to die violent deaths. The stability and integrity of Indian families appear to be collapsing. One out of three families live in crowded conditions. What is happening today is that Indians are beginning to understand their political rights, are willing to assert these, and, in the face of their social conditions, are willing to take action within Canada to better their position. We are all in for an interesting future in Western Canada in the 1980's. 


\section{GURSTON DACKS*}

I propose to begin by offering a few comments on Professor Sanders' paper. The first relates to his intriguing suggestion that aboriginal rights in law extend to the rights of self-determination, and that it can provide the basis for native self-government. It appears, as he says in his paper, that "the claims to land are logically a claim to the recognition of a set of legal rights established under Indian and Inuit customary law", and, the important point, "a law that has validity because Indian and Inuit communities had their own governments". The suggestion is that aboriginal rights flow from the fact that native peoples had their own governments.

The question I - as a non-lawyer - would put to him, is whether in the early Spanish definition or recognition of aboriginal rights, the notion was not so much one of the native people of South America having their own governments, but rather having souls like other human beings. This led to their being subject to equal rights under the law, or the equal protection of the law. Later recognitions of aboriginal title reflected not so much the fact that native peoples had, in effect, governments which established a system of law concerning ownership and use of land, but rather just that the native people were there when the white man arrived. That is to say, they occupied the land, so the question of occupancy rather than a legal regime was the point of issue. It is also possible that aboriginal title came to be established further because of a military necessity - the need to assure the friendship of particularly strategic native groupings.

Now if aboriginal title does not rest on a recognition of aboriginal selfgovernment, it is not clear to me that aboriginal title extends in law to the right of self-government. A piece of circumstantial evidence that can be proposed in advancing this thesis is simply that this line of argument seems not to have been advanced by native groups or proponents of the native position. It would seem that there has been ample opportunity for conflict concerning the extent of the sovereignty of provincial or federal authorities over native people for the issue to have arisen, yet the case seems not to have been put. This suggests the possibility that aboriginal title does not extend that far.

However, another possibility may be found in what I understand is a "rider" attached to the notion of aboriginal title. That is, that court judgments interpret aboriginal title as existing subject "to the goodwill of the Sovereign". The Sovereign can therefore extinguish aboriginal title. When a case is brought based on aboriginal title, the question is asked whether, in the act of legislating, the Crown has either explicitly or implicitly extinguished the aboriginal claim over a given piece of territory. The suggestion is that even if there were some right of self-determination contained within the notion of aboriginal title it would be a very limited one because it is contingent on the goodwill of the Crown. With that appreciation of aboriginal title we come to the question of the weight and significance of the proposed amendments to our constitution which entrench this kind of right. I do not think that the recognition of aboriginal rights, certainly with regard to questions of self-determination, is significant at all.

- Of the Department of Political Science, University of Alberta. 
With regard to its weight in terms of protecting hunting, fishing and trapping, I think the most recent judgment is the Baker Lake case ${ }^{1}$ which established exceedingly narrow and difficult grounds on the basis of which native people could protect themselves. To protect traditional hunting, fishing and trapping rights the native people, in effect the plaintiff, had to demonstrate not only that they did have aboriginal title over the area, but also that the proposed activity, in this case exploration for minerals, specifically uranium, significantly damaged or impaired their traditional use of the land. This is an argument which is difficult to prove. It requires the evidence of zoologists, environmentalists and so on, and it is not enough to prove that there will be some impairment. It must be significant impairment. So the Baker Lake case, while it certainly acknowledged the existence of aboriginal title, defined it in a fashion which is very narrow in law and quite expensive for the plaintiff to prove. And of course the plaintiffs, the people upon whom the burden of proof lies, are the native people, not those who would wish to impair their rights.

As a result, I am afraid that these amendments are not very substantial. What is needed is either a more sympathetic interpretation of the obligations of the government of Canada and of the Crown on the part of the courts, or a creative act on the part of Parliament, not just to affirm rights but to create rights. I must say that I am not tremendously optimistic about this policy eventuating. I would suggest, however, the possibility that there is sufficient uncertainty surrounding the question of aboriginal title that the federal government might be willing to show some flexibility in order to end this uncertainty and the possibility of litigation flowing from the question of aboriginal title. That litigation could obstruct the developmental goals of the federal government north of Sixty and embitter federal-provincial relations south of Sixty. In other words, the choices are not necessarily just extinguishment on the one hand, and entrenchment on the other hand, but possibly consolidation somewhere in the middle. 